Program effectiveness in facilitating intergenerational influence in environm...

Roy Ballantyne; John Fien; Jan Packer

The Journal of Environmental Education; Summer 2001; 32, 4; ProQuest Psychology Journals pg. 8

The Journal of Environmental Education, 2001, Vol. 32 No. 4 8-15

\title{
Program Effectiveness in Facilitating Intergenerational Influence in Environmental Education: Lessons From the Field
}

\author{
ROY BALLANTYNE, JOHN FIEN, and JAN PACKER
}

\begin{abstract}
Educators have invested considerable effort in developing environmental education programs that address students' knowledge, attitudes, and action competence regarding environmental issues. The authors explore the effectiveness of such programs in terms of both student learning outcomes and the intergenerational influence that results when students discuss their learning experiences with their parents and other community members. Six environmental education programs involving 284 students in Queensland schools, from Grades 5-12, were investigated. Students and their parents were surveyed and interviewed regarding their perceptions about the program, the program's influence on their environmental learning, and the extent and nature of discussions that the program stimulated between students and their parents. The authors draw conclusions about key features that should be incorporated into environmental education programs to encourage and empower students to bring about environmental change in their homes and communities.
\end{abstract}

Key words: environmental attitudes and behavior, environmental education, environmental program effectiveness, family communication, intergenerational influence

T here is little doubt that successive generations differ in the kinds of education they need to acquire at school (Strom, 1988). Strom argued that information is growing at such a rapid rate that each new generation is necessarily better informed than its predecessors and that children's

Roy Ballantyne in an associate professor of environmental education and interpretation at Queensland University of Technology. John Fien is an associate professor and director of the EcoCentre at Griffith University. Jan Packer is a research student and senior research assistant at Queensland University of Technology. knowledge base is often more up-to-date than that of their parents. Environmental education (EE) is one field to which this observation applies. Although students are becoming more environmentally literate and concerned, most adults rely on the media for EE. Although this is an effective means of influencing levels of environmental knowledge (Brothers, 1990), it is not generally successful in influencing environmental action (Finger, 1993).

Recognizing that the desire to protect the environment for the sake of future generations is a major source of motivation for adults, Ballantyne, Connell, and Fien (1998a) suggested that the process of intergenerational influence could potentially be a powerful means of enhancing adults" environmental knowledge, attitudes, and behavior. Inter- 
generational influence is the process through which young people can act as catalysts of environmental change among their parents and other adult members of the community (Uzzell, 1994).

Social science research indicates that children can actively influence their parents' values, attitudes, and decisions (Axinn \& Thornton, 1993; Cowan \& Avants, 1988; Glass, Bengston, \& Dunham 1986; Hagestad, 1984; Homer, 1993; Mangen, Bengston, \& Landry, 1988) in the areas of consumer choices, sports, leisure activities, and clothing style (Cheek \& Burch, 1976; Ekstrom, Tansuhaj, \& Foxman, 1986; Howard \& Madrigal, 1990; Peters, 1985; Polachek \& Polachek, 1989). Research in EE also provides some evidence that young people can effectively influence their parents' environmental awareness and actions (Kruger, 1992; Sutherland \& Ham, 1992; Uzzell, 1994). However, little is known about the extent to which school students discuss their experiences in environmental education programs, their understanding of and attitudes toward environmental issues, and their desire to take action in relation to environmental concerns with their parents or other adults.

To facilitate the process of intergenerational communication and extend the effect of school environmental education programs beyond the boundaries of the classroom, it is necessary to answer the following questions: (a) How effective are environmental education programs in promoting intergenerational communication about the environment? (b) What kinds of environmental education experiences tend to motivate students to share their school learning with their parents? and, (c) What steps can environmental educators take to encourage and assist their students in sharing their learning (including knowledge, attitudes and behaviors) at home?

Ballantyne, Connell, and Fien (1998b) presented some preliminary findings about these questions that indicate that students do share their environmental knowledge with their parents and that environmental education programs can adopt strategies that facilitate and encourage such sharing. In the present study, we support and extend these findings, drawing conclusions and insights from students' and parents' responses about a range of environmental education programs. First, in this article, we describe the programs and participants involved in the research and the techniques used for collecting data and conducting a thematic analysis across the cases described. Second, we present the results of this meta-analysis. Finally, we identify implications of the research for designing environmental education programs that can encourage intergenerational communication and learning.

\section{Method \\ Participating Programs, Students, and Parents}

We undertook case studies of six environmental education programs as part of this study. We studied formal and nonformal programs involving primary and secondary students (see Table 1). The programs addressed a range of issues (i.e., air pollution, water and energy use) and used a variety of pedagogical approaches (i.e., teacher and studentdirected strategies, hands-on activities, student data collection, and local action). A total of 284 students ( 192 girls and 92 boys) from nine schools contributed to the research by completing questionnaires. The participating schools included four private schools (three for girls and one for boys) and five state-government schools (all coeducationa). Schools were located in innercity (2), suburban (5), and rural (2) locations drawing students from a range of socioeconomic areas. Each student took home a questionnaire for parents to complete; we received 177 responses. We asked the respondents to indicate if they would also be willing to participate in a telephone interview. A total of 117 agreed. and we interviewed them. Most parents who responded were female $(78 \%)$

\section{Data Collection and Analysis}

We collected a range of quantitative and yualitative data about students' and parents" environmental knowledge, attitudes and behavior, the quality of intrafamily communication, students' enjoyment of the programs, their learning as a result of the program, and the extent to which they discussed aspects of the program with their parents (Ballantyne, Fien, \& Packer, 2001 ).

The findings reported in this article, however, are based on students' and parents' responses to qualitative questionnaires and interviews about the impact of the programs on student learning and student-parent discussion of the program. We asked students to complete a written questionnaire (which was administered in class and supervised by the class teacher) within 2-4 weeks of the end of the program. We also contacted parents within 2-4 weeks after the program and invited them to participate in a 15 -min telephone interview. During the interview, the researcher recorded the parents' responses. The questionnaire and interview explored the following topics:

- Student learning from the program. Students were asked to provide short written answers about what they had learned from the program, whether and in what ways the information they had learned was useful to their lives, and whether and in what ways the program had made them want to change. We asked parents what effect-if any-the environmental education program had on their child's behavior or attitudes.

- Aspects of the program that contributed to student learning. Students were asked which parts of the program had encouraged them to want to change.

- Student-parent discussion of the program. Students were asked if they had discussed (at home) what they had learned during the program, how much they had talked about it (a little, quite a lot, or lots), and what sorts of topics they may have discussed. Parents were also asked if the students had talked about the program and what was discussed. 
TABLE 1. Details About Participating Environmental Education Programs

\begin{tabular}{|c|c|c|c|c|}
\hline Program & Participants & Topic & Teaching Method & Duration \\
\hline \multirow[t]{2}{*}{ Airwatch } & $\begin{array}{l}32 \text { students } \\
\text { (aged 14-15) }\end{array}$ & $\begin{array}{l}\text { Air quality } \\
\text { Particle sampling } \\
\text { Car counting } \\
\text { Surveys }\end{array}$ & Class discussion & 1 month \\
\hline & $\begin{array}{l}16 \text { students } \\
\text { (aged } 12-15 \text { ) }\end{array}$ & Air quality & Voluntary activities during lunch hour & 1 year \\
\hline Six Thinking Hats & $\begin{array}{l}14 \text { parents } \\
73 \text { students } \\
\text { (aged } 13-17 \text { ) } \\
48 \text { parents }\end{array}$ & $\begin{array}{l}\text { Local environmental } \\
\text { problems }\end{array}$ & $\begin{array}{l}\text { Small group research } \\
\text { Oral presentations } \\
\text { De Bono's six thinking hats strategy } \\
\text { Written assignment }\end{array}$ & 5 months \\
\hline Kids, Companies, Creeks & $\begin{array}{l}35 \text { students } \\
(\text { aged } 13-17) \\
19 \text { parents }\end{array}$ & Water issues & $\begin{array}{l}\text { Class discussion } \\
\text { Interschool meetings } \\
\text { Observations } \\
\text { Surveys } \\
\text { Industry visits } \\
\text { Canoeing } \\
\text { Water-quality monitoring }\end{array}$ & 5 months \\
\hline $\begin{array}{l}\text { Issue Investigation, Action, } \\
\text { and Competence Project }\end{array}$ & $\begin{array}{l}26 \text { students } \\
\text { (aged } 9-11 \text { ) } \\
20 \text { parents }\end{array}$ & Self-selected issues & Small group investigation and action & 1 year \\
\hline Storywalk & $\begin{array}{l}79 \text { students } \\
\text { (aged } 9-12 \text { ) } \\
45 \text { parents }\end{array}$ & $\begin{array}{l}\text { Catchment } \\
\text { Awareness and land } \\
\text { use }\end{array}$ & $\begin{array}{l}\text { Role plays } \\
\text { Class discussion } \\
\text { Investigation } \\
\text { Water testing } \\
\text { Story } \\
\text { Experiential learning (in class and at environ- } \\
\quad \text { mental education center) }\end{array}$ & 5 months \\
\hline Powerwise & $\begin{array}{l}23 \text { students } \\
\text { (aged 11-12) }\end{array}$ & $\begin{array}{l}\text { Electricity (safety, } \\
\text { uses, conservation) }\end{array}$ & $\begin{array}{l}\text { Class discussion } \\
\text { Hands-on activity } \\
\text { Homework }\end{array}$ & 2 months \\
\hline
\end{tabular}

- Aspects of the program that stimulated student-parent discussion. Parents were asked about factors that might have triggered any discussion with their child about the environmental education program.

We qualitatively categorized students' and parents' responses to these questions, allowing the calculation of frequency statistics for descriptive purposes. We undertook this analysis in three stages: (a) grouping similar responses into categories; (b) defining the membership of and distinctions between categories; and (c) reclassifying responses according to the categories as defined.

\section{Results}

\section{What Did Students Learn From the Environmental Education Programs?}

We analyzed students' responses to questions about learning according to the types of learning they reported. Overall, $95 \%$ of students reported having learned something from the program in which they had participated. Although most students $(72 \%)$ reported having learned facts or information about a topic, significant numbers also reported learning skills in monitoring environmental problems $(18 \%)$, approaches to solving environmental problems (28\%), and new attitudes about environmental issues (35\%). Most important, $32 \%$ of students reported that they had changed their behavior in some way as a result of their participation in the program. The following student comments illustrate their learning:

Learning facts:

We learnt what were the sources of pollution and what type it was.

I learnt all about our catchment areas, about the different qualities of our water, i.e., turbidity, salinity.

Learning skills:

How to monitor the air we breathe and what's in it. We can now identify weeds and we can tell how polluted water is.

Learning approaches to solving environmental problems:

I have learnt how to help protect the creeks by being more careful about what I put down the sink. 
Which motor vehicles to buy that will affect the environment the least.

I learnt how I can help to save the frogs.

Learning new attitudes:

I have learnt it is hazardous to pollute the earth . . . it has made me care more.

I learnt that water is precious and should definitely be conserved.

Changing behaviors:

I do regular clean-ups of the creek now.

I save water (turn the tap off) and save electricity (turn off light) when not in use.

Use less water and use biodegradable things.

Parents were also asked if they had observed any changes in their children as a result of their participation in the environmental education programs. Overall, $82 \%$ of parents reported observing some degree of change in their children. In particular, they said that their children were more aware of or interested in environmental issues (61\%), had changed their attitudes toward environmental issues (19\%), or had changed their behavior in some way $(22 \%)$. The following comments illustrate these observations.

\section{Interest/awareness:}

She's a little more aware of what is going on around her in terms of the environment.

A big reason why he chose Earth Science next year was because of his exposure to this program - so it helps them to carry on an interest in the environment.

Attitudes:

It certainly fired her enthusiasm to consider things we can do for our environment and look at things for koala fund raising.

\section{Behavior:}

I have noticed she turns off the shower. It used to be a battle with her over taking long showers... She is more environmentally conscious.

\section{What Aspects of the Programs Influenced Student Learning?}

Students' responses shed some light on aspects that contribute to environmental education programs" success in achieving goals for student learning. Four types of experience-each of which was included in at least three of the six programs-were cited in response to the question about parts of the program that had made students want to change (see Table 2). Students most frequently cited the opportunity to test water or air quality in the local environment. In the four programs in which water or air testing was incorporated, $27 \%$ of students reported this feature as a factor contributing to change. Considering that $46 \%$ of students gave no response to this question, it is apparent that nearly half of the students who responded referred to this particular activity. Student comments supported these findings.

When we tested the creek water and our results showed how bad the pollution really was.

Particle collectors-seeing the rubbish in the air.

Students cited the presentation or discussion of information about environmental issues as the second most important influence (19\% of all students in the six programs; $35 \%$ of those who responded to the question). In particular, focusing class discussion on environmental problems that students were able to observe in their homes or local areas seemed to arouse student enthusiasm and commitment to the topic, while enabling teacher input and direction. In this regard, students cited the following features.

Learning about pollutants and where they come from.

Mainly the facts helped me change my mind.

Learning about how many people waste water.

Environmental experiences (e.g., planting trees, cleaning creeks, canoeing, and taking rainforest walks) helped to raise awareness and influence environmental attitudes among students (cited by $18 \%$ of all students in the three programs in which environmental experiences were incor-

TABLE 2. Percentages of Students in Each Program Who Cited Aspects That Influenced Their Learning

\begin{tabular}{|c|c|c|c|c|c|}
\hline Program & $\begin{array}{l}\text { Testing and } \\
\text { monitoring }(\%)\end{array}$ & $\begin{array}{c}\text { Information } \\
\text { and discussion }(\%)\end{array}$ & $\begin{array}{l}\text { Environmental } \\
\text { experiences (\%) }\end{array}$ & Projects (\%) & $\begin{array}{l}\text { Response } \\
\text { rate }(\%)\end{array}$ \\
\hline Airwatch & 19 & 8 & - & 6 & 31 \\
\hline Six Thinking Hats & 10 & 37 & - & 15 & 60 \\
\hline Kids, Companies, and Creeks & 46 & 14 & 6 & 9 & 69 \\
\hline Issue Investigation, Action, and Competence & & & & & \\
\hline Project & - & 8 & 12 & 12 & 31 \\
\hline Powerwise & - & 13 & - & 4 & 17 \\
\hline Storywalk & 41 & 15 & 23 & - & 72 \\
\hline Total & 27 & 19 & 18 & 10 & 54 \\
\hline
\end{tabular}

Note. Dashes indicate an aspect that was not completed during the program. 
porated: $26 \%$ of respondents to the question).

When I saw the creek and animals living there I wished people would look after it better so I decided to start caring.

Seeing the scrub turkey with string around its leg.

Finally, students reported that involvement in individual and group projects-especially those requiring information collection (e.g., from organizations or internet searches) or field research (e.g., surveys or car counting)-had a major influence on their learning (cited by $10 \%$ of all students in the five programs in which these activities were incorporated; $22 \%$ of respondents to the question). Often, students undertook these projects as homework and presented their results in class:

Since I did the test (electricity audit), me and my whole family have been trying to save power.

Researching and giving the spoken presentation helped me want to change.

Researching-found out how much we need to do.

Although water and air quality testing could also fall into this category, this form of information collection was maintained as a separate category because of the frequency of responses that specifically mentioned these aspects.

Parents' comments reveal some additional insights into the effect of various aspects of the programs on the students. In particular, parents noted the importance of focusing on a local issue, demonstrating the existence and consequences of local environmental problems, and encouraging students to take positive action in the local environment.

Mainly because it was in her immediate area. I feel it was a worthwhile exercise to research something herself. It makes it very real/meaningful for them and gets them more interested rather than doing it on some book or fictional story-it hits home

Unless kids see it they do not think it affects their lives. So it made them interested in our locality. It made her aware that is was not just oil and petrol there are other sorts of pollution and that people do not care.

It was great that the girls were able to make a difference, rather than just see it's polluted. It enforced that they can make a difference in their local area. They got to see the point of view from companies, which live along the creek. It broadened their horizons-now they can see both sides. They saw that companies care for the environment too. So that is heartening - they can see that change is possible and that there is hope.

\section{Did Students Discuss Their Learning With Their Parents?}

Overall, $73 \%$ of students reported having discussed the program with their parents at least once; in most cases, they had discussed it on more than one occasion. Although the frequency of program discussion was quite high, the nature of this discussion varied widely. Some students (19\%) simply described or commented on the program or its associated activities without sharing any information or perspec- tives that might be relevant or meaningful to their parents' environmental behavior. For example.

I told Mum what we do and who is in the group.

How to do water testing and how great the program is.

Other students (26\%) shared environmental information or discussed environmental issues with their parents after their environmental education experiences.

The different things that are being found in creek water.

The Brisbane River is brown due to dredging.

How much pollution there really is in Brisbane.

Finally, $28 \%$ of students reported that they had discussed with their parents actions that could be taken in the home and local community (that the students had learned about as a direct result of their experience in the program).

I told them not to waste electricity.

I asked whether they bought electrical saving devices.

What household products can be substituted for things that affect the environment.

I talked to my uncle about how polluted the creek is and what he should do to help save it.

Students' claims were verified in interviews with parents (see Table 3). An even greater percentage of parents reported discussion than did students, but this may have been because of the data collection method (interviews rather than questionnaires). A particularly encouraging finding of this study was that approximately half of all students in the six environmental education programs took home some sort of environmental message and discussed environmental issues or action with their parents. For example, parents commented.

We talked about what was going on in the creeks, for example, how much toxins were found in the water. We chatted about how it should be cleaned, how everything should go back to basics.

She told me that $72 \%$ of air pollution is from cars alone which means there is only another $28 \%$ from trucks and other transport. ... She told me that Brisbane is in the middle of a belt-we get pollution from north and south - they call it an airshed. She also pointed out how breathing in particles is bad for you, which she is concerned about because she is an asthmatic.

She talked about the pollution in the creek next to the school.

We were discussing which factory it came from.

Her Dad works in a cannery. It has a smoke stack. She asked her Dad how it worked and whether the factory thought about what it spits into the air.

Some parents also confirmed that, during these discussions, they had been challenged to change their attitudes or household practices:

It brought home more of an awareness of what we should all be doing. 
TABLE 3. Students' and Parents' Reports About the Nature of Discussion Stimulated by the Environmental Education Programs

\begin{tabular}{lcc}
\hline \hline & \multicolumn{2}{c}{ Reports } \\
\cline { 2 - 3 } Nature of discussion & $\begin{array}{c}\text { Student (\%) } \\
\text { (valid } n=267)\end{array}$ & $\begin{array}{c}\text { Parents (\%) } \\
\text { (valid } n=92)\end{array}$ \\
\hline $\begin{array}{l}\text { Program only } \\
\text { Program AND an } \\
\quad \text { environmental issue } \\
\text { or information (but }\end{array}$ & 19 & 39 \\
$\quad$ NOT action) & 26 & \\
$\begin{array}{c}\text { Program AND } \\
\text { environmental action }\end{array} \quad$ & 28 & 27 \\
$\quad$ Total (any discussion) & 73 & 90 \\
& & \\
\hline
\end{tabular}

It reminded us to make sure we don't do the wrong thing in terms of what we get rid of

We will plant more native trees.

She told me when cleaning the bathroom I should use vinegar now.

She turns the tap off and makes sure everyone else does.

\section{What Aspects of the Programs Facilitated Student- Parent Discussion?}

Parents' comments about the circumstances that triggered discussion with their children are helpful in revealing aspects of environmental education programs that facilitate intergenerational transfer of learning. In particular, parents reported that discussion had arisen mostly as a result of projects that students were required to do as homework or presentations that the students were giving at school or in the community. The following comments illustrate this influence:

I helped my daughter with her research. We researched it at Daisy Hill Koala Centre. We talked about speed limit signs on Mt. Cotton Road and erecting koala signs. We discussed the fact that dogs are a domestic problem for koalas and that Chlamydia is a big problem in our area.

My daughter had to write an assignment on pollution in the local area. She had to get facts about it. We talked about who was responsible, how it could be cleaned up, and what were the causes of pollution.

I went through her project with her and we talked about lack of habitat, the history of habitat decline since European settlement, and what people can do to protect habitats.

She went through her oral with me. She asked us what the word "atmosphere" meant and then it expanded from there. She asked me what would be the best things to do to help fix the problem.

Parents also reported that some discussion had arisen as a result of students' participation in uncommon or particu- larly enjoyable activities or experiences-in most cases out of the classroom.

The kids tend to only discuss things that they do not usually expect in class, something that is a little different.

However, parents' comments suggest that discussion arising because of this novelty factor is more likely to center on the program itself rather than the environmental issue or possible actions.

He talked mainly about doing water testing at a primary school; he really enjoyed that.

The thing we heard the most about was the excursion to visit the creek.

She was quite excited; the newspaper came to the school and interviewed the girls.

Finally, some parents noted that the duration or ongoing nature of the program was significant in bringing it to attention at home.

It was an event that went on for a while ( 5 weeks) that was discussed at home.

It got everyone in the family involved. We would be asking her what she is doing next. You can't really learn about this sort of information normally. Once a week there should be an environmental program for the kids.

Some doubt was cast on this suggestion by observations from an earlier pilot study (Ballantyne, Connell, \& Fien, 1998b), which indicated that even a $1 / 2$ hour, one-time visit to an environmental center could trigger discussion at home. However, discussion of this shorter program did tend to focus on the program itself, rather than environmental issues or actions.

\section{Conclusions and Implications for Environmental Education Programs}

The possibility that school environmental education programs can play a vital role in promoting intergenerational discussion about environmental matters (in the home and the community) is an exciting one. Our findings are encouraging because they demonstrate that students can and do share their learning and environmental attitudes with their parents and that they can and do bring about positive change in household practices. That this change occurred across a range of environmental education programs (involving students from a range of age groups and schools) supports the generalizability of this finding. In this article, we have highlighted some of the factors that may facilitate intergenerational communication and learning in the home, which need to be further investigated through ongoing research.

Environmental education programs often incorporate novel activities that are interesting and fun. Such activities influence young people to initiate discussion about the program at home; often, such discussion remains at the level of "I enjoyed the program" rather than progressing to discussion of environmental issues and actions. Simply enjoying a program is clearly not enough if the aim of environmental 
education programs is to promote environmental learning, responsible attitudes, and action.

Hands-on activities (i.e., monitoring water quality in a local creek, measuring air pollution, or observing the effects of litter on local wildlife) are not only interesting and fun but also have a powerful influence on students' interest in and awareness of environmental problems. These students are likely to share their interest and concern with their parents and other adults in the community. Focusing on a local environmental problem in this way helps to make the problem real to students and encourages a greater sense of ownership. Combining monitoring or project activities, environmental experiences, and class discussion optimizes student learning, arouses student enthusiasm and commitment to a topic and helps to integrate students' abstract (theoretical or scientific) understanding of environmental problems with their concrete (practical or everyday) experience of them.

Our findings also reinforce the importance of including an action component in environmental education programs. Providing positive experiences-that demonstrate to students that they can have an influence in their own local environment - not only helps to overcome the action paralysis identified by Uzzell and Rutland (1993) but is also likely to lead to meaningful and relevant discussions with parents regarding environmental issues and the need for community action. Even young children can influence everyday household practices such as walking or riding a bike to school, taking shorter showers, turning off taps and lights, and purchasing environmentally friendly cleaning products.

Students' and parents' responses suggest several ways in which school environmental educators can encourage discussion of environmental issues in the home. For instance, programs can be designed to involve parents in activities such as homework assignments, research activities, and class presentations. These activities stimulate intergenerational communication that is potentially educative for parents and students. The programs in this study also involved parents and other community members by (a) conducting surveys and interviews to identify people's perceptions of environmental issues, (b) presenting project reports and research findings in a public forum, (c) having the program reported in the local newspaper, (d) asking local industries to demonstrate their environmental management strategies, and (e) involving local business and community groups in environmental action projects.

Finally, the finding that approximately half of all students participating in school-based environmental education programs take an influential message about environmental issues and actions home to their parents highlights the potential power and effectiveness of school students as catalysts and agents of community attitude and behavior change. This finding suggests that teachers may be able to widen their perceptions about their audience to include students' parents by consciously considering this point in the planning of environmental education lessons. Thus, we hope that this article will challenge environmental educators to build a balanced selection of features that will facillitate and encourage the process of intergenerational communication and influence into their programs.

\section{ACKNOWLEDGMENTS}

The research reported in this article was conducted under an Australian Research Council Large Grant. The authors thank Sharon Connell for her contribution $\omega$ this project.

\section{REFERENCES}

Axinn, W. G., \& Thornton. A. (1993). Mothers, children and cohabitation The intergenerational effects of attitudes and behavior. Anerican Sociological Revien: 58, 233-246.

Ballantyne, R. Connell. S.. \& Fien, J. (1998a). Students as catalysts of environmental change: A framework for researching intergenerationa influence through environmental education. Environmental Education Research. 4(3), 285-298.

Ballantyne, R. Connell, S., \& Fien, J. (1998b). Factors contributing to intergenerational communication regarding environmental programs: Preliminary research findings. Australian Joumal of Environmental Education, 14. 1-10.

Ballantyne, R., Fien, J.. \& Packer. J. (2001). Intergenerational influence in environmental education: A quantitative analysis. Australian Journal of Environmental Education. 17.

Brothers. C. C. (1990). The impact of television on public environmental knowledge concerning the Great lakes. Unpublished master's thesis. Ohio State University, Columbus

Cheek, N. H.. \& Burch. W. R. (1976). The social organisation of leisure in human society. New York: Harper \& Row.

Cowan, G., \& Avants, S. K. (1988). Children's influence strategies: Structure, sex differences, and bilateral mother-child influence. Child Devel opment, 59, 1303-1313.

Ekstrom, K.. Tansuhaj. P., \& Foxman. E. (1986). Children's influence in family decisions and consumer socialisation: A reciprocal view. In $M$. Wallendorf \& P. Anderson (Eds.I. Advances in consumer research Vol. 14. Provo, UT: Association for Consumer Research.

Finger, M. (1993). Does environmental learning translate into more responsible behavior? Nature Herald, 4, 9-10.

Glass, J., Bengtson, V. L.. \& Dunham. C. C. (1986). Attitude similarity in three-generation families: Socialization, status inheritance, or reciprocal influence? American Sociological Review: $5 /$ (October). 685-698.

Hagestad, G. O. (1984). The continuous bond: A dynamic multigenerational perspective on parent-child relationships between adults. In $\mathrm{M}$. Perlmutter (Ed.), Parent-child interaction and parent-child relations in child development: Minnesota Simposium on Child Psychology: New York: Erlbaum

Homer, P. A. (1993). Transmission of human values: A cross-cultural investigation of generational and reciprocal influence effects. Genetic; Social, and General Psuchologi, 119(3). 343-367.

Howard, D. R., \& Madrigal, R. (1990). Who makes the decision: The parent or the child? The perceived influence of parents and children on the purchase of recreation services. Journal of Leisure Research. 22(3). $244-258$

Kruger, J. (1992). The influence of children on decision-makers in their homes: A case study in enrommental education. Unpublished master's thesis, Rhodes University, South Africa.

Mangen D. J.. Bengston, V. L.., \& Landry. P. H. (Eds.) (1988). Measurement of intergenerational relation. Newbury Park: Sage.

Peters, J. F. (1985). Adolescents as socialisation agents to parents. Adolescence, $20(8), 921-933$.

Polachek, D. P., \& Polachek, S. (1989). An indirect test of children`s influence on efficiencies in parental consumer behavior. Joumal of Comsumer Affairs, 23(1), 91-110.

Strom. R. (1988). Intergenerational learning and curriculum development. Educational Gerontology, 14, 165-181.

Sutherland, D., \& Ham, S. (1992). Child-to-parent transfer of environmental ecology in Costa Rican families: an ethnographic case study. The Journal of Environmental Education, 23(2), 9-16. 
Uzzell. D. (1994) Children as catalysts of environmental change (Final rep.) London: European Commission Directorate General for Science Research and Development Joint Research Centre.

Uzzell, D.. \& Rutland, A. (1993. July). Intergenerational social influence:
Changing environmental competence and performance in children and adults. Discussion paper presented at the Second International Workshop on Children as Catalysts of Global Environmental Change, Lniversity of Braga, Portugal.

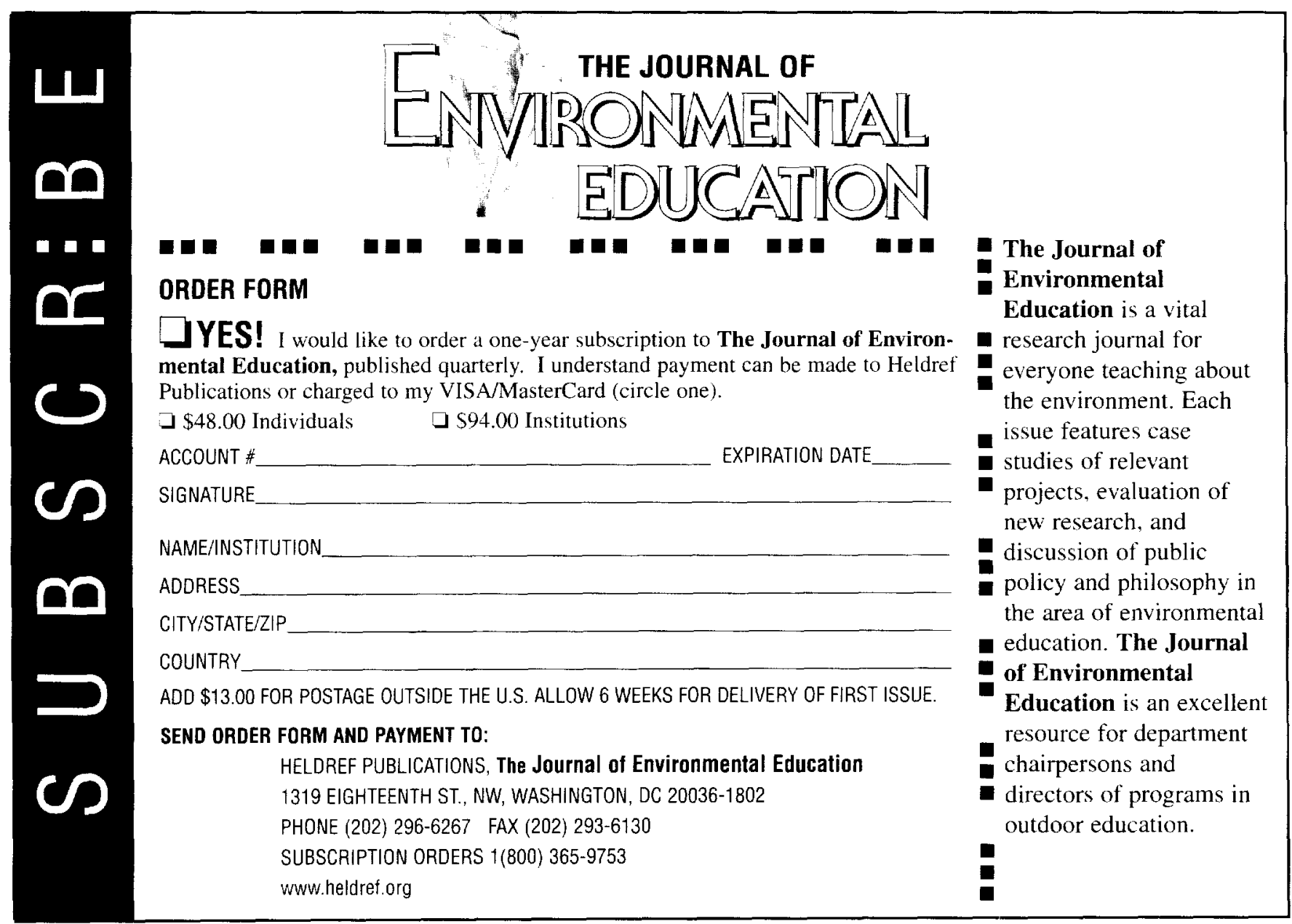

